\title{
Test Anxiety and Academic Self-Concept of Students
}

\author{
Gagandeep Kaur ${ }^{1}$, Senthil Kumaran $\mathrm{J}^{2 *}$
}

\section{ABSTRACT}

The study aimed at exploring the relationship of Academic self-concept and Test Anxiety of students and to find out the differences in these two variables with respect to some selected categorical variables. The objectives included (i) to find out the differences in Test anxiety and Academic Self-concept with respect to gender, stream of study and academic self-appraisal; and (2) to find out the relationship between Test anxiety and Academic Self-concept. For this purpose, 200 students studying various streams from a university were selected through stratified random sampling keeping gender and stream of study as strata. Academic Self Concept Scale by Liu, Wang \&Parkins (2005) and Fried-Ben Test anxiety Scale (FTAS) by Friedman \&Bendas Jacob (1997) were utilized to collect data. The data analysis revealed significant differences in test anxiety and academic self-concept of students with respect to their gender, course of study and academic self-appraisal. Also, significant inverse correlation was found between test anxiety and academic self-concept. Thus the study aligned with the existing literature. Implications and suggestions are posed as how the findings can be utilized for school consultation and in which direction the further research can be executed.

Keywords: Test Anxiety, Academic Self-Concept, Gender, Course, Academic Self-Appraisal, University Students

Since the beginning of formal education system, achievement in written exams has been given significant attention and is strengthened time and again. Students are in a need to reveal their uniqueness to the globalized job market. For the sake unique identity, parents and teachers insist students to perform well in exams. Also, students are self-determined to achieve high in exams. However, only a handful of students succeed in this journey and many end up in perceiving these tests as threats rather than as opportunities to excel and develop anxiety. The under achievement of academically pro-active students without any significant- irreversible cognitive disabilities is the current problem remaining unsolved in the campus settings. Since the academic evaluation through high stakes testing is perceived as crucial, anxiety clouds their performance. The anxiety

\footnotetext{
${ }^{1}$ School Counselor, Akal Academy, Baru Sahib, Distt. Sirmore, Himachal Pradesh, India

${ }^{2}$ Assistant Professor, Department of Psychology, Kristu Jayanti College (Autonomous), Bangalore, Karnataka, India *Corresponding Author

(C) 2016 I G Kaur, S Kumaran; licensee IJIP. This is an Open Access Research distributed under the terms of the Creative Commons Attribution License (http://creativecommons.org/licenses/by/2.0), which permits unrestricted use, distribution, and reproduction in any Medium, provided the original work is properly cited.
} 
associated with tests is termed as Test Anxiety in psychology literature and is defined as "a set of physiological, phenomenological and behavioural responses that accompany concern over possible negative consequences or failure in an exam or similar evaluative situations" by Sieber, O’Neil \& Tobias (1977).

Test anxiety is a condition characterized by worries which arise in test situations with the symptoms of common anxiety. Giddiness, shivering of limbs, disturbed sleep, insecurity, elevated heart beat and feel of dread, include the symptoms of anxiety. These symptoms are demonstrated to hamper the test performance of students by altering cognitive, affective and conative processes related to testing situations. Testing practice is conceptualized to yield elevated anxiety and associated inverse influences on test performance. So far, various researches demonstrated that test anxiety is debilitating the academic performance of students. Test anxiety is demonstrated to be decreasing the student's attention and result in increased errors (Ohata, 2005; Sarason, 1986). Culler and Holahan (1980) determined that high testanxious students performed more poorly and had a higher dropout rate than low anxious students. Test anxiety research has its origin since 1900s (Zeidner, 1998) with a vast literature and diversified theoretical models. However, test anxiety is repeatedly found to be explored with related psychological constructs in academic context.

One such construct which holistically describes the academic attribute of students is Academic self-concept. Generally, self-concept is one of the most important constructs in psychology and allied social sciences that is well explored and demonstrated that enhancement of self-concept results in positive productivity in diverse settings (Branden, 1994; Marsh \& Craven, 1997). In such a perspective, academic self-concept is defined as domain specific self-concept which explains about the way the students perceived and conceptualized about their ability in academic settings (Rosen, Glennie, Lennon, \&Bozick, 2010). Academic self-concept is well related to academic achievements and it has been exposed in many studies (Trautwein, Ludtke, Koller, \&Baumert, 2006; Hamacheck, 1995). The reciprocal relationship of academic self-concept and academic achievement is demonstrated by Guay, Marsh, \&Boivin, (2003).

In all these light, the present study was aimed at exploring the test anxiety with academic selfconcept and to see the differences in these variables with respect to few selected categorical variables namely gender, course of study, academic self-appraisal. The study was expected logically to be aligning with the existing literature in test anxiety and academic self-concept and categorical differences. Thus, the need to study the relationship between test anxiety and academic self-concept is conceptualized.

\section{OBJECTIVES}

1. To study the differences in test anxiety and academic self-concept of students on the basis of their gender.

2. To study the differences in test anxiety and academic self-concept of students on the basis of their course of study.

(C) The International Journal of Indian Psychology, ISSN 2348-5396 (e)| ISSN: 2349-3429 (p) | 91 
3. To study the differences in test anxiety and academic self-concept basis of their academic self-appraisal.

4. To study the relationship between test anxiety and academic self-concept of students.

\section{Hypotheses}

1. There is a significant difference in the dimensions of test anxiety of students with respect to their gender.

2. There is a significant difference in the dimensions of academic self-concept of students with respect to their gender.

3. There is a significant difference in the dimensions of test anxiety of students with respect to their course of study

4. There is a significant difference in the dimensions of academic self-concept of students with respect to their course of study

5. There is a significant difference in the dimensions of test anxiety of students with respect to their academic self-appraisal

6. There is a significant difference in the dimensions of academic self-concept of students with respect to their academic self-appraisal

7. There is a significant relationship between the dimensions of test anxiety and the dimensions of academic self-concept of students.

\section{METHOD}

Normative survey method was implemented for data collection in the present study. Simple random sampling technique was followed to derive sample $(n=200)$ of students aging 18-21 years, studying in a university. The derived sample was administered using (i) Fried-Ben Test Anxiety Scale (FTAS) by Friedman \& Bendas-Jacob (1997) with cronbach alpha - 0.82. This scale has 26 items dispersed in three dimensions namely social derogation, cognitive obstruction and tenseness with 6-point rating scale starting from ' 1 ' does not characterize me to ' 5 ' characterizes me well. Social derogation refers to the worries of being socially belittled and criticized by noteworthy others after a failure on tests while cognitive obstruction specifies a disturbed concentration, difficulty in recall, troubles in effective problem solving, before or during a stringent test and tenseness refers to the physical and affective discomfort. (ii) Academic self-concept Scale by Liu, Wang \& Parkins (2005) with cronbach alpha- 0.77. This scale has 19 items spread in two dimensions viz. students' confidence and students' effort. Respondents are supposed to rate how they perceive their ability in academic settings on a 4point scale ranging from ' 1 ' strongly disagree to '4' strongly agree. The collected data were analyzed using independent sample ' $t$ ' test, one way analysis of variance (ANOVA) and Pearson's product moment correlation. 


\section{RESULTS AND DISCUSSION}

\section{Table - 1: Test anxiety and Academic Self Concept of students on the basis of Gender via} Independent sample ' $t$ ' test.

$$
\text { ======= Insert Table } 1 \text { here }======
$$

From Table-1, it is inferred that the students do not significantly differ in social derogation $(t=1.434)$ and cognitive obstruction $(t=0.264)$ dimensions of test anxiety with respect to their gender. However, significant differences are found in the tenseness $(t=3.072)$ dimension and also, while considering test anxiety total $(t=2.076)$. Female students scored higher (tenseness $=$ $19.17 \pm 6.71$, test anxiety total $=65.19 \pm 18.86$ ) than male students (tenseness $=16.38 \pm 6.12$, test anxiety total $=60.36 \pm 13.62)$. Additional inference from the mean and matching standard deviation scores, female students accounted for high proneness in test anxiety than male students Therefore, it can be stated that test anxiety of students as a variable, has significant difference with respect to their gender. Few studies (Altermatt\& Kim, 2004; Hembree, 1988) indicated this difference and suggested to look for the factors that determine a heightened test anxiety in female students. Hence, hypothesis (1) stating "There is a significant difference in the dimensions of test anxiety of students with respect to their gender" is accepted.

From the same table, it is also found that the students do not significantly differ in the dimensions of academic self-concept viz. students' confidence ( $t=0.584)$ and students' effort $(t=1.11)$ with respect to their gender. Hence, hypothesis (2) stating "There is a significant difference in the dimensions of academic self-concept of students with respect to their gender" is not accepted.

Table - 2: Test anxiety and Academic self-concept of students on the basis of Course via One way Analysis of Variance

======= Insert Table 2 here $======$

From table-2, it is observed that the students differ significantly in social derogation $(F=3.128)$ and cognitive obstruction ( $F=3.854$ ) dimensions of test anxiety with respect to their course of study. It is clear that the students belonging to humanities and education discipline scored least (19.72) in social derogation dimension, preceded by students of allied medical sciences (21.58) and those of business \& applied arts (23.84). Comparatively, students studying science \& technology courses showed a high score (24.32) in social derogation. This result can be attributed to the reason that students belonging to science \& technology internalize the pressure of getting good marks in exams than the students from other courses. Also, they are more concerned about getting belittled by the significant others because of poor performance in exams. Further, it is inferred that in cognitive obstruction dimension, students of allied medical sciences (20.56) scored least, preceded by science \& technology students (21.10) and humanities \& education students (24.16). Students belonging to business \& applied arts (24.72) scored high in cognitive obstruction dimension of test anxiety. It is inferred that students belonging to business

(C) The International Journal of Indian Psychology, ISSN 2348-5396 (e)| ISSN: 2349-3429 (p) | 93 
\& applied arts find difficult to think clearly in testing situation than their counterparts from other courses. Hence, hypothesis (3) stating "There is a significant difference in the dimensions of test anxiety of students with respect to their course of study" is accepted.

From the same table, it is also found that the students do not significantly differ in the dimensions of academic self-concept viz. students' confidence $(F=2.016)$ and students' effort $(F=0.348$ ) with respect to their course of study. Hence, hypothesis (4) stating "There is a significant difference in the dimensions of academic self-concept of students with respect to their course of study" is not accepted.

\section{Table - 3: Test anxiety and Academic self-concept of students on the basis of their Academic self-appraisal via One way Analysis of Variance} $======$ Insert Table 3 here $======$

The students were asked to rate themselves based on their academic performance. The options given were (a) Above average, (b) Average and (c) Below average. From table-3, it is observed that the students differ significantly in cognitive obstruction $(F=10.182)$ dimension of test anxiety with respect to their academic self-appraisal. It is clear that the students self-appraised as below average (28.57) scored high, followed by those who reported average (23.77). Students who self-appraised as above average (19.11) reported low in cognitive obstruction dimension of test anxiety. This is all about perception of one's self regarding academic performance. Further, it is inferred that there is no significant difference found in social derogation ( $F=1.954)$ and tenseness dimensions of test anxiety with respect to their academic self-appraisal. It is clear that students who reported themselves as average exhibited high concern regarding others' perspective and comparative those who reported themselves as below average did not worry about what others think I terms of exam performance. Hence, hypothesis (5) stating "There is a significant difference in the dimensions of test anxiety of students with respect to their academic self-appraisal" is accepted for cognitive obstruction dimension but not accepted for social derogation and tenseness dimensions of Test Anxiety.

Also, it is seen from the same table that students differ in the dimensions of academic selfconcept viz. students' confidence ( $F=14.631)$ and students' effort $(F=4.179)$ on the basis of their academic self-appraisal. In students' confidence dimension, It is found that the students selfappraised as above average (28.77) in academics scored high, followed by those reported average (25.85) and the students who self-appraised as below average (23.43). It is of the logic that academic self- concept score of students is aligned with their academic self-appraisal. Also, it is found that in students' effort dimension of academic self-concept, students self-appraised as above average (29.36) in academics scored high, followed by those reported average (27.61) and the students who self-appraised as below average (25.86). The descending order of mean scores implies that the single item opinion, academic self-appraisal of students is found significantly differing in their academic self-concept as per the logic. Hence, hypothesis (6) stating "There is a 
Test Anxiety and Academic Self-Concept of Students

significant difference in the dimensions of academic self-concept of students with respect to their academic self-appraisal" is accepted. Thus, the results highlight the logical order and difference.

\section{Table - 4: Relationship between Test anxiety and Academic self-concept of students via Pearson's product moment correlation}

$$
======\text { Insert Table } 4 \text { here }======
$$

From table-4, it is inferred that significant inverse correlations are found between dimensions of test anxiety with that of academic self-concept except for Students' effort with social derogation $(r=-0.126)$ and tenseness $(r=-0.138)$. The students' confidence dimension of academic selfconcept is inversely correlated with social derogation $(r=-0.166)$, cognitive obstruction $(r=-$ $0.528)$, tenseness $(r=-0.206)$ and with test anxiety total $(r=-0.415)$. This result states that the students who lack confidence in their academic performance tend to exhibit more concern regarding belittled by significant others due to poor exam performance. Moreover these students tend to get disturbed in their cognitive activities necessary for test taking and suffer from bodily arousal. It is also seen that the Students' effort dimension of academic self-concept is inversely correlated with cognitive obstruction $(r=-0.443)$ and test anxiety total $(r=-0.327)$. The logical relationship expected before the study was found to be true. Academic self-concept comprises of the students' confidence and their efforts in academic tasks. It is vivid that the students who are confident and with good morale regarding their academics will not be having debilitating test anxiety. Thus, they would tend to assume test anxiety as a challenge to be faced rather having threat perception. The same applies for the students' effort dimension of academic self-concept where the students employing sufficient efforts in their academic tasks will be in the right path of performing well in exams. Hence, the inverse relationship found in the analysis is logical. Also, few studies quoted that the variables similar to students' confidence (Putwain, 2010), students' efforts (Culler \&Holahan, 1980; Michaels, \&Miethe, 1989; Pintrich, \& De Groot, 1990), and self-concept in general (Williams, 1993) were substantiated oninverse correlations with test anxiety.

\section{CONCLUSION}

Test anxiety has been demonstrated in the literature as debilitating the test performance of students. Academic self-concept is the perception of students about their abilities in academic settings. Previous researches in the field of school psychology specified the importance of exploring the test anxiety of students with various psychological and demographic variables noteworthy for their academic settings especially with those facilitate their academic performance and equip them to deal with test anxiety. Hence the present study aimed at exploring test anxiety with academic self -concept. In order to verify the differences in the sample, demographic variables viz. gender, course of study and academic self-appraisal were included. From findings of this study, it is seen that the female students have higher tenseness than their male counterparts. Also, students belonging to science \& technology discipline showed

(C) The International Journal of Indian Psychology, ISSN 2348-5396 (e)| ISSN: 2349-3429 (p) | 95 
higher test anxiety than those studying business \& applied arts, allied medical sciences and humanities \& education. Gender and Course of study categories did not reveal any differences in academic self-concept but significant differences were found in academic self-concept with respect to academic self- appraisal. The test anxiety and academic self-concept of students are inversely correlated with test anxiety and academic stress. It is a certain call of school administrations to opt for school consultation with psychologists to deal with the worrying issue of test anxiety and poorly formed academic self-concept by applying suitable interventions. The school psychologists may reflect these findings while designing academic skill development programs for students. Further, it is suggested that the future directions of the present study include (i) in-depth analysis of interaction between test anxiety dimensions and academic selfconcept using multivariate statistical operations such as multiple regression and path analysis, (ii) Developing an educational cum intervention program for assuaging test anxiety and enhancing academic self-concept and demonstrating its worth, and (iii) identification of other latent dimensions of test anxiety and testing their relationship with academic self-concept in order to propose an indigenous measurement model.

\section{REFERENCES}

[1] Altermatt, E.R. and Kim, M.E. (2004). Can Anxiety Explain Sex Differences in College Entrance Exam Scores?.Journal of College Admission Spring, 6-11.

[2] Branden, N. (1994). Six pillars of self-esteem. New York: Bantam.

[3] Culler, R. E., \&Hollahan, C. J. (1980). Test anxiety and academic performance: The effects of study related behaviors. Journal of Educational Psychology, 72, 16-20.

[4] Friedman, I.A., \&Bendas-Jacob, O. (1997). Measuring Perceived Test anxiety in Adolescents: A Self-Report Scale. Educational and Psychological Measurement, 57(6), 1035-1046.

[5] Guay, F., Marsh, H. W., \&Boivin, M. (2003). Academic self-concept and academic achievement: Developmental perspectives on their causal ordering. Journal of Educational Psychology, 95 (1), 124-136.

[6] Hamacheck, D. (1995). Self-concept and School Achievement. Interaction Dynamics and a Tool for Assessing Self-concept Component. Journal of Counselling and Development, 73, 419-425.

[7] Hembree, R (1988). Correlates, causes, effects, and treatment of test anxiety. Reviews in Educational Research, 58, 47-77.

[8] Liu, W. C., Wang, C. K. J., \&Parkins, E. J. (2005). A longitudinal study of students' academic self-concept in a streamed setting: The Singapore context. British Journal of Educational Psychology, 75(4), 567-586.

[9] Marsh, H. W., \& Craven, R. (1997). Academic self-concept: Beyond the dustbowl. In G. Phye (Ed.), Handbook of classroom assessment: Learning, achievement, and adjustment (131-198). Orlando, FL: Academic Press.

[10] Michaels, J. W., \&Miethe, T. D. (1989). Academic effort and college grades. Social Forces, 68(1), 309-319. 
[11] Ohata, K. (2005). Potential Sources of Anxiety for Japanese Learners of English: Preliminary Case Interviews with Five Japanese College Students in the U.S., The Electronic Journal for English as a Second Language, 9(3), 1-21.

[12] Pintrich, P. R., \& De Groot, E. V. (1990). Motivational and self-regulated learning components of classroom academic performance. Journal of educational psychology, 82(1), 33.

[13] Putwain D.W., \& Daniels, R. A. (2010). Is the relationship between competence beliefs and test anxiety influenced by goal orientation? Learning and Individual Differences. 20(1), 8-13.

[14] Rosen, J. A., Glennie, E. J., Dalton B. W., Lennon, J. M., and Bozick, R. N. (2010). Academic self-concept. Noncognitive Skills in the Classroom: New Perspectives on Educational Research. RTI Press publication No. BK-0004-1009. Research Triangle Park, NC: RTI International.

[15] Sarason, I. G. (1986). Test anxiety, worry, and cognitive interference. In R. Schwarzer (Ed.), Self-relatedcognitions in anxiety and motivation. Hillsdale, NJ: Erlbaum.

[16] Sieber, J. E., O’Neil Jr., H. E, \& Tobias, S. (1977). Anxiety, learning and instruction. Hillsdale, New Jersey: Erlbaum.

[17] Trautwein, U., Ludtke, O., Koller, O., \&Baumert, J. (2006). Self-esteem, academic selfconcept, and achievement: How the learning environment moderates the dynamics of selfconcept. Journal of Personality and Social Psychology, 90, 334-349.

[18] Williams, J.E. (1993). The relationship of Test Anxiety and Self-concept to Patterns of High School Students Achievement. Journal Midwestern - Educational Researcher, 6(2), 7-12.

[19] Zeidner, M. (1998). Test Anxiety. The state of the art. Plenum press: New York.

The following tables need to be inserted at the corresponding spaces during formatting

Table - 1: Test anxiety and Academic Self Concept of students on the basis of Gender via Independent sample 't' test.

\begin{tabular}{|l|c|c|c|}
\hline \multicolumn{1}{|c|}{ Variables \& Dimensions } & \multicolumn{2}{c|}{ Mean (S.D) } & \multirow{2}{*}{ 't' value } \\
\cline { 2 - 3 } & $\begin{array}{c}\text { Male } \\
(\mathbf{n = 1 0 0 )}\end{array}$ & $\begin{array}{c}\text { Female } \\
(\mathbf{n = 1 0 0 )}\end{array}$ & \\
\hline Test Anxiety - Social Derogation & $21.49(7.79)$ & $23.24(9.39)$ & $1.434^{\text {N.S. }}$ \\
\hline Test Anxiety - Cognitive Obstruction & $22.49(6.61)$ & $22.78(8.78)$ & $0.264^{\text {N.S. }}$ \\
\hline Test Anxiety - Tenseness & $16.38(6.12)$ & $19.17(6.71)$ & $3.072^{*}$ \\
\hline Test Anxiety Total & $60.36(13.62)$ & $65.19(18.86)$ & $2.076^{*}$ \\
\hline $\begin{array}{l}\text { Academic Self-Concept - } \\
\text { Students Confidence }\end{array}$ & $26.75(4.05)$ & $26.42(3.94)$ & $0.584^{\text {N.S. }}$ \\
\hline $\begin{array}{l}\text { Academic Self-Concept - } \\
\text { Students Effort }\end{array}$ & $27.69(4.06)$ & $28.38(4.69)$ & $2^{\text {N.S. }}$ \\
\hline
\end{tabular}

N.S. - Not Significant at 0.05 level; * - Significant at 0.05 level/ $(\mathrm{df}=198)$ 
Table - 2: Test anxiety and Academic self-concept of students on the basis of Course via One way Analysis of Variance

\begin{tabular}{|c|c|c|c|c|c|}
\hline \multirow[b]{2}{*}{ Variables and Dimensions } & \multicolumn{4}{|c|}{$\begin{array}{c}\text { Course } \\
\text { (Mean Scores) }\end{array}$} & \multirow{2}{*}{$F(3,196)$} \\
\hline & $\begin{array}{l}\text { Sc\&T } \\
(n=50)\end{array}$ & $\begin{array}{l}\text { B\&AA } \\
(n=50)\end{array}$ & $\begin{array}{c}\text { H\&E } \\
(n=50)\end{array}$ & $\begin{array}{c}\text { AMS } \\
(n=50)\end{array}$ & \\
\hline Test Anxiety - Social Derogation & $24.32^{b}$ & $23.84^{\mathrm{a}, \mathrm{b}}$ & $19.72^{\mathrm{a}}$ & $21.58^{\mathrm{a}, \mathrm{b}}$ & $3.128^{*}$ \\
\hline $\begin{array}{l}\text { Test Anxiety - Cognitive } \\
\text { Obstruction }\end{array}$ & $21.10^{\mathrm{a}, \mathrm{b}}$ & $24.72^{b}$ & $24.16^{\mathrm{a}, \mathrm{b}}$ & $20.56^{\mathrm{a}}$ & $3.854^{*}$ \\
\hline Test Anxiety - Tenseness & $17.84^{\mathrm{a}}$ & $18.82^{\mathrm{a}}$ & $17.78^{\mathrm{a}}$ & $16.66^{\mathrm{a}}$ & $0.906^{\text {N.S. }}$ \\
\hline $\begin{array}{l}\text { Academic Self-Concept - } \\
\text { Students Confidence }\end{array}$ & $27.26^{\mathrm{a}}$ & $26.00^{\mathrm{a}}$ & $25.80^{\mathrm{a}}$ & $27.28^{a}$ & $2.016^{\text {N.S. }}$ \\
\hline $\begin{array}{l}\text { Academic Self-Concept - } \\
\text { Students Effort }\end{array}$ & $28.42^{\mathrm{a}}$ & $27.56^{\mathrm{a}}$ & $27.96^{\mathrm{a}}$ & $28.20^{\mathrm{a}}$ & $0.348^{\text {N.S. }}$ \\
\hline
\end{tabular}

1. T\&Sc -Sciences\&Technology; B\&AA- Business \& Applied Arts; H\&E-Humanities \& Education; AMSAllied Medical Sciences.

2. N.S. - Not Significant at 0.05 level; * - Significant at 0.05 level

3. ${ }^{\mathrm{a}, \mathrm{b}}$ - Tukey'sPosthoc subsets (where $\left.\mathrm{a}<\mathrm{b}\right) /(\mathrm{df}=3,196)$

Table - 3: Test anxiety and Academic self-concept of students on the basis of their Academic self-appraisal via One way Analysis of Variance

\begin{tabular}{|l|c|c|c|c|}
\hline \multirow{2}{*}{\multicolumn{1}{|c|}{ Variables and Dimensions }} & \multicolumn{2}{c|}{$\begin{array}{c}\text { Academic Self-Appraisal } \\
\text { (Mean Scores) }\end{array}$} & \multirow{2}{*}{ F (2,197) } \\
\cline { 2 - 4 } & $\begin{array}{c}\text { Above } \\
\text { Average } \\
(\mathbf{n = 5 6 )}\end{array}$ & $\begin{array}{c}\text { Average } \\
(\mathbf{n = 1 3 7 )}\end{array}$ & $\begin{array}{c}\text { Below } \\
\text { Average } \\
(\mathbf{n = 7})\end{array}$ & \\
\hline Test Anxiety - Social Derogation & $20.80^{\mathrm{a}}$ & $23.16^{\mathrm{a}}$ & $19.29^{\mathrm{a}}$ & $1.954^{\text {N.S. }}$ \\
\hline Test Anxiety - Cognitive Obstruction & $19.11^{\mathrm{a}}$ & $23.77^{\mathrm{a}, \mathrm{b}}$ & $28.57^{\mathrm{b}}$ & $10.182^{*}$ \\
\hline Test Anxiety - Tenseness & $16.75^{\mathrm{a}}$ & $18.40^{\mathrm{a}}$ & $13.71^{\mathrm{a}}$ & $2.698^{\text {N.S. }}$ \\
\hline $\begin{array}{l}\text { Academic Self-Concept - } \\
\text { Students Confidence }\end{array}$ & $28.77^{\mathrm{b}}$ & $25.85^{\mathrm{a}, \mathrm{b}}$ & $23.43^{\mathrm{a}}$ & $14.631^{*}$ \\
\hline $\begin{array}{l}\text { Academic Self-Concept - } \\
\text { Students Effort }\end{array}$ & $29.36^{\mathrm{b}}$ & $27.61^{\mathrm{a}, \mathrm{b}}$ & $25.86^{\mathrm{a}}$ & \multirow{2}{*}{$4.179^{*}$} \\
\hline
\end{tabular}

1. N.S. - Not Significant at 0.05 level; * - Significant at 0.05 level

2. ${ }^{\mathrm{a}, \mathrm{b}}$ - Tukey'sPosthoc subsets (where $\left.\mathrm{a}<\mathrm{b}\right) /(\mathrm{df}=2,197)$

Table - 4: Relationship between Test anxiety and Academic self-concept of students via Pearson's product moment correlation

\begin{tabular}{|l|l|l|l|l|}
\hline \multicolumn{1}{|c|}{$\boldsymbol{r}$} & $\begin{array}{l}\text { Social } \\
\text { Derogation }\end{array}$ & $\begin{array}{l}\text { Cognitive } \\
\text { Obstruction }\end{array}$ & Tenseness & $\begin{array}{l}\text { Test Anxiety } \\
\text { Total }\end{array}$ \\
\hline Students Confidence & $-0.166^{*}$ & $-0.528^{*}$ & $-0.206^{*}$ & $-0.415^{*}$ \\
\hline Students Effort & $-0.126^{\text {N.S }}$ & $-0.443^{*}$ & $-0.138^{\text {N.S }}$ & $-0.327^{*}$ \\
\hline
\end{tabular}

1. ${ }^{\text {N.S. }}$ - Not Significant at 0.05 level; * - Significant at 0.05 level

How to cite this article: G Kaur, S Kumaran (2016), Test Anxiety and Academic Self-Concept of Students, International Journal of Indian Psychology, Volume 3, Issue 4, No. 56, ISSN 23485396 (e) | ISSN: 2349-3429 (p), DIP: 18.01.009/20160304, ISBN: 978-1-365-23992-2 